\title{
A measuring instrument to evaluate e-service quality in a revenue authority
}

\section{setting}

\author{
Madeleine Stiglingh \\ Professor and Head of Department \\ EMS 4-9 \\ Economic and Management Science Building \\ Department of Taxation \\ University of Pretoria \\ Pretoria \\ South Africa \\ E-mail address: madeleine.stiglingh@up.ac.za \\ Tel: +27124203346
}

Tax revenue forms the backbone of any economy. The quality of the e-services provided by a revenue authority is therefore crucial, as e-service quality directly influences the burden of complying with tax obligations, and hence affects the tax compliance climate in a country. The aim of the study is the development of a measuring instrument that encapsulates the 'lens of a tax practitioner' in an e-service revenue authority setting. In order to develop a conceptual framework, an in-depth, qualitative approach was used to identify a comprehensive range of service attributes and dimensions that potentially drive e-service quality in the revenue authority setting. This framework is then compared with other relevant service quality models to derive at a proposed eservice quality measuring instrument. Findings from this study may advance the understanding and the management of the e-service quality of the e-services in a revenue authority setting.

Keywords: Critical incident technique, revenue agency, tax collection agency, e-service quality, tax practitioner 


\section{Highlights}

- Critical incident study where positive responses exceed negative responses

- Electronic service quality framework for a tax collection agency

- Measuring instrument to measure electronic services of tax collection agency

\section{Introduction}

High on the agenda of the 2013 G8 summit held in Northern Ireland was the issue of increased tax compliance in both developed and developing countries. Maybe the leaders of the G8 countries did not have to meet to try to solve the tax compliance dilemma. The solution might be much closer to home. Revenue authorities should perhaps spend more time on improving the services it renders to the taxpayers and tax practitioners. It is conceptualised that better service quality management of the services rendered to taxpayers and tax practitioners might impact the trust in the tax authority and also influence tax compliance (Feld \& Frey, 2002; Gangl, Meuhlbacher, De Groot, Goslinga, Hofmann, Kogler, Antonides \& Kirchler, 2013; Meuhlbacher and Kirchler, 2010; Murphy, 2004).

Services rendered by revenue authorities could either be rendered through expensive labour intensive off-line channels or via less expensive electronic platforms (e-services). Improving the service quality of the e-services would increase the usage and reuse thereof. The Treasury Department of the United States reports annual savings of $\$ 78$ million from the move from paper based to electronic tax services (United States Treasury, 2008). Electronic tax services, however, hold many more advantages for a government than just cost and human resource savings. Fewer error rates, increased compliance and freed resources that the government can use for more complicated tax cases and evasion, are just a few of these advantages (Connolly \& Bannister, 2008). It is, therefore, evident that the adoption of the electronic tax service would be beneficial to the 
government. One of the major factors which influence a person's decision to adopt e-services is the quality of that service (Rotchanakitumnuai, 2008). Asubonteng and McClearly (1996), Hu, Brown, Thong, Chan, and Tam (2009) and Pinho, De Lurdis Martins and Macedo (2011) found that increased service quality also increases the intention to reuse the specific service.

E-service usage at tax authorities would not only reduce the costs for the tax authority, but effective e-services would also decrease the costs for the taxpayers to comply with their tax obligations. Many taxpayers today resort to using tax practitioners to find some relief from their tax obligations. It is estimated that tax practitioners represent approximately 4 million of the 6.3 million South African tax paying taxpayers (SARS, 2007; Snyckers, 2006). However, tax practitioners charge for their services. The more onerous it is for a tax practitioner to deal with a taxpayer's tax obligations, the higher the charge for the service; therefore the higher the direct costs involved in collecting the $\operatorname{tax}$.

Connoly, Bannister and Kearney (2010) state that an understanding of the e-service expectation of the tax practitioner is required. Robledo (2001) states that understanding 'the lens of the customer' is a prerequisite for delivering superior service, since customers (in this case tax practitioners) evaluate e-service quality by comparing their perceptions of the service with their expectations. When a tax authority knows the e-service quality expectations relevant to the tax practitioners, it becomes possible to identify how to manage the e-service quality of the services rendered to them (Gaster \& Squires, 2003; Grönroos, 1988; Seth, Deshmukh, \& Vrat, 2005). Better service quality management of the e-services rendered to tax practitioners might impact the trust in the tax authority and also influence taxpayer compliance (Feld \& Frey, 2002; Meuhlbacher \& Kirchler, 2010; Murphy, 2004). 
Only a limited number of studies (Barnes \& Vidgen, 2007; Connolly \& Bannister, 2008; Hu et al., 2009; Rotchanakitumnuai, 2008) have contributed to the understanding of e-service quality from the taxpayer's or tax practitioner's perspective. These studies do, however, not fully encapsulate the e-service quality perspective of a tax practitioner in a tax authority setting. Tax practitioners represent the majority of taxpayers in a South African context. Smulders, Stiglingh, Franzsen and Fletcher (2012) provided evidence that $76 \%$ of small businesses in South Africa make use of the services of tax practitioners. It is submitted that tax practitioners not only represent the majority of taxpayers, but that the frequency of their interaction with the South African Revenue Services (SARS) is probably much higher than that of an individual taxpayer. Therefore, they are probably the individuals best able to identify service excellence and deficiencies with regard to the services SARS delivers. Tax practitioners also fulfil an important mediating role and serve as a conduit for SARS by passing information to the most affluent taxpayers, which may inevitably influence decisions taken by these taxpayers, as Smith (2003) points out.

The objective of this research is to examine the e-service quality perspective of a tax practitioner in a tax authority setting in South Africa. An in-depth, qualitative approach using the critical incident technique is used to identify a comprehensive range of attributes and dimensions that potentially drive e-service quality in the revenue authority setting. These dimensions are presented in an eservice quality framework that encapsulates the 'lens of the tax practitioner' as suggested by Johnson and Gustafsson (2000). This 'lens of the tax practitioner' is then evaluated against the most widely used generic e-service quality survey instrument to determine its applicability in a revenue authority setting.

This paper commences with a review of studies relevant to the e-service quality of a revenue authority. Thereafter the research methodology followed in this research is discussed. The proposed 
e-service quality framework and its comparison with the service quality scales from the literature are then presented, followed by the conclusion.

\section{Previous research on service quality}

Quality can be defined in various ways. The user-based approach starts with the premise that quality is not an objective thing, but is 'in the eyes of the beholder' (Berry, Zeithaml, \& Parasuraman, 1985; Garvin, 1984; Philip \& Stewart, 1999). It is also widely agreed that service quality depends on two variables: expected (desired) service and perceived service. Grönroos $(1984,1988)$ found that perceived service quality is the outcome of an evaluation process where the expected service is compared with the service received.

Service quality was defined mainly by means of service quality models. Two schools of thought emerged in the definition of service quality, namely the Scandinavian and American schools. The Scandinavian school defined service quality using categorical terms and divided the construct into different dimensions. Originally Grönroos (1984) identified three dimensions: the Technical dimension ("what"), the Functional dimension ("how") and the Corporate image.

The American school of thought defined service quality using more descriptive terms, but also divided the construct into different dimensions. The dimensions identified by Parasuraman, Zeithaml, and Berry (1985, 1986, 1988, 1991a) are Tangibility, Reliability, Responsiveness, Assurance and Empathy. These authors also developed the first service quality measuring instrument, SERVQUAL. Other authors, such as Richard and Allaway (1993) and Vos (2003) found that SERVQUAL was widely accepted as a robust categorisation of the dimensions of service. Some authors, for example, Cronin and Taylor (1992), Dabholkar, Shepherd, and Thorpe (2000) and Donnelly and Shiu (1999), have questioned the distinctness of SERVQUAL's fivefactor structure. Another scale called SERVPER, that was developed by Cronin and Taylor (1992) 
has the same dimensions as SERVQUAL. In the SERVPER scale Cronin and Taylor (1992) suggests that service quality is better predicted by performance only and not as the difference between performance and expectations.

Lee and Lin (2005) and Vos (2003) have successfully adjusted SERVQUAL - that was originally developed for the measurement of off line services - to evaluate e-service quality in the e-service environment. Many other researchers have found that e-service quality is influenced by dimensions that differ from traditional service quality (Cox \& Dale, 2001; Santos, 2003; Zeithaml, Parasuraman, \& Malhotra, 2002; Zhu, Wymer, \& Chen, 2002). Many authors then started to specifically develop e-service quality models.

Szymanski and Hise (2000) in their e-Satisfaction model have examined the dimensions of esatisfaction and not e-service quality. Connoly et al. (2010) states that the e-Satisfaction model excludes dimensions of website service quality such as fulfilment. Some researchers, such as Johnson and Gustafsson (2000) and Marx (2005), avoid addressing the difference between service quality and satisfaction and use both terms interchangeably in practice and in theory. By contrast, other researchers, such as Czepiel, Solomon, Surprenant and Gutman (1985), Dabholkar et al. (2000), Olivier (1993), Parasuraman et al. (1986), Rust, Zahorik and Keiningham (1995), Schneider and White (2004) and Spreng and Mackoy (1996) argue that, while service quality and customer satisfaction are related, they are two distinct constructs.

Yoo and Donthu (2001) developed a nine item scale (SITEQUAL) with four dimensions, Ease of use, Aesthetic design, Security and Processing to measure online service quality of an internet shopping site. Connolly et al. (2010) are of the opinion that this scale excludes dimensions considered central to the evaluation of website service quality and this scale might therefore not be relevant in this setting. 
Loiacono, Watson and Goodhue's (2002) e-service quality scale proposes four higher order dimensions, namely Usefulness, Ease of use, Entertainment and Complementary relationship. The first higher order dimension, Usefulness, consists of information fit-to-task, interactivity, trust and response time dimensions. Two dimensions, ease of understanding and intuitive operations are classified under the second Ease of use higher order dimension. Entertainment, the third higher order dimension encapsulates the visual appeal, innovativeness and flow-emotional appeal dimensions. The fourth higher order dimension, Complimentary, is represented by consistent image, on-line completeness and better than alternative channels dimensions. Connolly et al. (2010) state that it is unclear whether this instrument provides a specific service quality measure from a customer's perspective.

Li, Tan and Xie (2002) adapted the SERVQUAL instrument with consideration of the differences between online and offline services with six dimensions, Responsiveness, Competence, Quality of information, Empathy, Web assistance and Call back systems. Tan, Xie and Li (2003), the same authors who adapted the SERVQUAL instrument, also present another instrument and they call it eSERVQUAL. This e-SERVQUAL instrument consists of 11 dimensions that is Reliability, Responsiveness, Access, Flexibility, Ease of navigation, Efficiency, Assurance/trust, Security, Site aesthetics, Customization/ personalization and Quality of information. The authors in their research do not compare the two scales with each other and does not seem to be clear what scale, if any, would be suitable in a tax authority setting.

Barnes and Vidgen (2002) in their WebQual scale identified five factors that are grouped into three main dimensions that are Usability (site design and usability), Information quality (quality of the content of the site) and Interaction quality (embodied in trust and empathy). The authors of WebQual question the applicability of WebQual to the public sector and specifically e-government services and also transactions with degrees of complexity (i.e. online tax filing). As WebQual could 
also be completed by a user that did not complete the entire purchasing process, it seems as if this instrument does not constitute a comprehensive assessment of e-service quality. Connoly et al. (2010) seem to agree with this view and is also of the opinion that WebQual focuses on a transaction-specific assessment rather than a detailed service quality assessment of a website. Despite their own concerns, Barnes and Vidgen (2007) changed the name of the scale to E-Qual and subsequently made use of this instrument to assess the quality of the United Kingdom's Inland Revenue web site. They, however, did not validate the use of E-Qual within an online taxation environment. The authors state that a follow up on their study requires detailed interviews with site users to define service quality for online taxation systems. The authors found that the most important dimensions were the Ease of use, Safety of personal information and Accurate, trusted and pertinent content.

Wolfinbarger and Gilly (2003) proposed the eTailQ scale with Website design, Fulfilment/Reliability, Privacy/Security and Customer service as relevant dimensions. Parasuraman, Zeithaml, and Malhotra (2005) have expressed a need for caution regarding the consistency and appropriateness of service dimensions used in this scale.

Parasuraman et al. (2005) developed a multi-item scale that is divided into normal services (E-SQual), recovery services (E-RecS-QUAL), perceived value and loyalty intentions. Four service dimensions are relevant to the E-S-Qual higher order dimension of their scale, namely Efficiency, System Availability, Fulfilment and Privacy. A further three service dimensions were identified in the E-RecS-Qual dimension, namely Responsiveness, Compensation and Contact. The Perceived Value dimension includes four statements. The Loyalty Intention dimension consists of five statements. The combined scale developed would, for the purpose of the current research, be referred to as E-S-Qual. Collier and Bienstock (2006) applaud the E-S-Qual scale as an important 
step in conceptualizing e-service quality. The E-S-Qual measuring scale for e-service quality has been successfully used by various other researchers (Kim, Kim \& Lennon, 2006; Meckovec, Bubas \& Vrcek, 2007; Nomdoe \& Pather, 2007). Boshoff (2007) did a psychometric assessment of the ES-Qual scale and found that E-S-Qual is a valid and reliable instrument. He concluded that it was the most effective scale to measure the quality of e-services. Yaya, Marimon and Fa (2012) reviewed the E-S-Qual scale and found that the dimensions tend to be contingent on the service industry. Even in the same industry, the dimensions depend on the type of user. It appears that the dimensions of Efficiency, System availability and Privacy appear consistently in all variations. The Fulfilment dimension appears not to be generic and relates more to the selling of physical goods. ES-Qual has received the most recognition of all the instruments that have been proposed for measuring e-service quality and the scale is effective in capturing the core of e-service quality (Yaya, et al., 2012). The E-S-Qual scale can thus be regarded as an e-service quality measuring instrument with a high degree of validity that is applicable globally in both the private and the public sectors.

Collier and Bienstock (2006) developed and tested a conceptual e-service quality framework that consists of three second-order dimensions of Process quality, Outcome quality and Recovery. These authors believe that e-service quality is made up of formative rather than reflective indicators. Parasuraman et al. (2005) state that calling scale items formative or reflective indicators of latent constructs is a challenging issue. Ladhari (2010) suggests that further studies are needed to examine the formative conceptualization of e-service quality in greater depth. In Collier and Bienstock's (2006) framework they propose 11 first-order dimensions for measuring e-service quality. The five first order dimensions relate to the Process quality and are Privacy, Design, Information accuracy, Ease of use and Functionality. The next three first order dimensions make up Outcome quality, namely Order timeliness, Order accuracy and Order condition, The last three first order dimensions contribute to the second order dimension, Recovery, and is Interactive fairness, 
Procedural fairness, and Outcome fairness. The authors postulate that Process quality evaluations bias evaluations of the Outcome quality. These findings seem to confirm earlier findings by Grönroos (1984) who argues that a bare minimum Technical quality (Outcome quality) is always required, but that Functional quality (Process quality) is the most important. He claimed that it could even compensate for temporary problems with the Technical quality. According to Klaus (1985), Congruence (initial social interaction) is the first condition of good service quality. Technical quality (which he refers to as task achievement) is the second condition to be met for achieving service quality. The final level is the Psychological aspects (functional quality, excluding initial social interaction). Although it is important that Collier and Bienstock (2006) reopened the formative or reflective nature debate of e-service quality, their framework was not empirically validated.

The E-GOVSQUAL-RISK model was later developed by Rotchanakitumnuai (2008) to identify the dimensions that citizens use in assessing the quality of e-government in an e-revenue context. Interviews were conducted with a small sample of 30 individual taxpayers in Thailand. This scale proposes four service quality dimensions, namely Service design quality, Web site design quality, Technical support and Customer support quality. Given that Donnelly and Shiu (1999) suggest that culture may influence service quality perceptions, the study conducted in the Asian region may not necessarily be applicable to tax practitioners in the African region. The interviews were semistructured, which may also have resulted in the inclusion of service quality aspects that would not necessarily represent the 'lens of the customer'. This model was based on the views of a small sample of individual taxpayers - other types of taxpayers, such as corporates, were not represented. As this study was conducted in a revenue authority setting, the relevance of this scale deserves further investigation. 
$\mathrm{Hu}$ et al. (2009) state that e-service quality is jointly determined by service characteristics and technology characteristics. They, in identifying the dimensions of service quality of online tax services in Hong Kong, adapted SERVQUAL for the service characteristics. They used previously validated scales to measure all the constructs related to the technology characteristics. For the measurement of continuance intentions, they have identified four additional dimensions, namely Perceived usefulness, Perceived ease of use, Security and Convenience. The authors state that further research is required to identify new service quality dimensions that would be particularly appropriate for e-services in a revenue authority setting. This scale was also developed from an extensive review of existing service quality models and might therefore not fully encapsulate the opinions of users of online tax services. It requires further investigation.

Sigala $(2009,2012)$ proposes the expansion of existing e-service quality models to also include the role of customer participation and inter-customer support in e-services. Although the results of this study are very important for the private sector, the role of customer participation and inter-customer support in the public sector is not yet clear. As the relationship between a revenue authority and a taxpayer is regulated by legislation, customer participation and inter-customer support are not relevant in a revenue authority setting.

After an extensive literature review, Connolly et al. (2010) slightly adjusted the general multi-item scale (E-S-Qual) that was developed by Parasuraman et al. (2005), in order to evaluate the e-service quality of the Irish tax collection agency. They adjusted the E-S-Qual instrument with input from the revenue agency itself. A new scale is presented (E-PS-QUAL) with six dimensions for service quality being made up of Perceived public value, Ease of completion, Efficiency, Privacy, System availability and Contact. Connoly et al. (2010) found that there is a clear difference between the factors that are important to users of taxation e-services and those using commercial e-services. 
Papadomichelaki and Mentzas (2011) propose a scale (e-GovQual) for the measurement of egovernment services. The scale consists of four main quality dimensions that are Efficiency, Trust, Reliability and Citizen Support. As SARS falls within the public sector domain, the numerous service quality models developed specifically for e-government might also be relevant to this research. However, the normal e-government service quality models would not necessarily meet the requirements of revenue authorities, as the e-services used in the tax environment are more complex than those used in most other e-government services (Arkinci, Atilgan-Inan, \& Aksoy, 2010). As this e-GovQual scale was developed recently and within the South African context, the relevance of this scale in the revenue authority context should be investigated.

Pinho et al. (2011) do not propose an e-service quality measuring instrument, but identify the eservice quality dimensions that most strongly relate to intentions of certified accountants (therefore tax practitioners) to use the e-services of a revenue authority. They have found that the Degree of convenience associated with internet use, Speed and ease of access, Privacy and Security to have the most effect on the degree of e-service usage.

Ladhari (2010), in a literature review of most e-service quality instruments, found that Reliability/Fulfilment, Responsiveness, Ease of use/Usability, Privacy/Security, Web design and Information quality/benefits seems to be the key dimensions in e-service quality evaluations. He also found that it seems that there is no generic measuring instrument, but that all generic instruments should be complemented by sector-specific dimensions. The author also recommends that the development of industry-specific quality measurement scales is a fruitful avenue of future research.

This research attempts to bring us one step closer to an industry-specific measurement scale for a revenue authority setting. From the literature review it seems as if the scales developed by Barnes 
and Vidgen (2007), Connolly et al. (2010), Hu et al. (2009), Parasuraman et al. (2005), Papadomichelaki and Mentzas (2011) and Rotchanakitumnuai (2008) could have relevance in a revenue authority setting.

The research methodology in taking us one step closer in understanding service quality in a revenue authority setting from a tax practitioner's perspective is presented next.

\section{Research methodology}

The research can be categorised as falling within the qualitative paradigm and, more specifically, an interpretive orientation, which is an approach that seeks to understand phenomena and to develop theory or build models or frameworks that can be tested empirically in later research (Cooper \& Schindler 2001; Leedy \& Ormrod 2005; Welman et al. 2005). Using a qualitative paradigm is in line with the view of Ladhari (2010) who states that a researcher should use qualitative research methods at the earliest stage in developing e-service quality measurement scales. One such qualitative method is the critical incident technique, which relies on a set of procedures to collect comments on service experiences, perform a content analysis and classify the observations. One of the advantages of the critical incident technique is that the context is developed entirely from the respondent's perspective and in his or her own words, and that the observations are not restricted to a limited set of variables or activities (Bitner, 1990; Gremler 2004; Odekerken-Schröder, Van Birgelen, Lemmink, De Ruyter \& Wetzels 2000).

Gremler (2004) established that the critical incident technique has been used successfully in a variety of service contexts in the last three decades: more than 140 critical incident technique studies have appeared in marketing research in the service context. More than 125 of these studies have been published since 1990 . The most frequently researched issue using the critical incident technique is customer evaluations of service ( $31 \%$ of its use), including issues related to service 
quality (Gremler, 2004). In the focus groups that Parasuraman et al. (1985) conducted for the development SERVQUAL, they also employed the critical incident technique to elicit examples of when customers were satisfied with a service and when they were not. The critical incident technique is thus exactly what is required for building the "lens of the customer". Bitner (1990), Johnson and Gustafsson (2000) and Ladhari (2010) regard this technique as particularly well suited for this purpose.

The critical incident data were collected by means of four open-ended questions which tax practitioners who were registered with SARS in terms of section 67A of the Income Tax Act (Act No 58 of 1962) were asked to complete. These questions were included as part of a larger webbased survey administered by SARS. The purpose of the survey was to establish the perceptions that tax practitioners hold with regard to the quality of the services rendered by SARS. It was stated on the questionnaire that the results will, firstly, be used by SARS to develop their service strategy to tax practitioners and, secondly, be used to assist in building a service quality instrument that could be used in future to assess the service quality of SARS.

In the four questions included in the questionnaire the tax practitioners responding to the survey were requested to list the things they "extremely appreciate" (Question 1 for the service channels and Question 3 for the business processes) and then the things they "extremely dislike" (Question 2 for the service channels and Question 4 for the business processes) about their interactions with SARS. Johnson and Gustafsson (2000) recommend a range of between five and ten responses for each category. Because there are different service channels likely to elicit different perceptions of service quality levels, it was thought that a range of five responses would perhaps limit the number of responses. The respondents were therefore encouraged to list as many experiences as possible and an open block without any range was provided on the web based questionnaire. 
The total population of approximately 17000 tax practitioners returned 811 completed questionnaires, which represents a response rate of approximately 5\%. The responses were collated by SARS and forwarded to the researcher who did not have any power to increase the response rate. This response rate may be considered satisfactory, because the average response rate for questionnaires in marketing-related studies is often as low as 5\% (McDaniel and Gates, 1996, cited in Odekerken-Schröder et al., 2000) and because the purpose of these open-ended questions is to assist in an exploratory study.

The data analysis involved three processes. The first was the identification of usable critical incidents; the second was the development of a classification scheme for the content analysis and the third was a content analysis of the identified critical incidents.

The analysis procedure advocated by Flanagan (1954) indicates that the critical incident itself is the basic unit of analysis and 'an incident is critical if it makes a 'significant' contribution, either positively or negatively to the general aim of the activity'. The insertion of the word "extremely" in the wording of the questions attempted to ensure that only aspects of significance were reported.

On the questions of what tax practitioners 'extremely appreciate', the following are examples of critical incidents reported:

I work long hours and can do work after normal office hours with the 24 hours availability of e-filing.[7.22]

The quickest way to get a response is through the e-filing section by telephone. The people working there at the moment have really been trained well, but please leave them there until the system is running. [8.13] 
I am pleased with the e-filing system as one knows the return is completed to SARS satisfaction. [24.7]

On the 20th Nov I had an appointment with a lady at Randburg iro efiling. It was the best I had been treated ever by SARS. She should be a role model for all SARS personnel. [34.15]

On the questions of what tax practitioners 'extremely dislike', the following are examples of critical incidents reported:

The SARS e-filing systems are the BEST thing SARS has implemented. However - if the site is down it is terrible. I foresee MAJOR MAJOR problem at end Jan 2008 when everybody wants to submit returns - as the site WILL CRASH. [10.13]

E-filing tax returns not available for certain individuals, takes forever to remove a taxpayer from your portfolio, can't submit cc, pty or trust returns via efiling. Expected to have this functionality for trusts by now, waited and didn't submit via hardcopy, now sitting with the problem that if this functionality is not available by 28 February next year, penalties for late submission of trust tax returns. [20.4]

With efiling especially, they take too long to answer the phone. I never get useful help they do not understand efiling ...most of them. Sometimes they actually hang up on me. [24.16]

E-Filing does not have the facility to manually remove organizations or taxpayers from your profile to a sort of "Organization/Individual history" file. Some E-Filing returns are assessed very fast while it seems that others are put on hold. [33.8] 
The efiling system is frustrating that it becomes slow and unusable during peak periods, we are practitioners who help make sure people are compliant, and basically ensure revenue collection. By using your system we are subjected to system lag due to SARS allowing the general population to use the system and it is beyond irritating. We should have separate servers etc. to prevent this. [34.41]

Although tax practitioners were requested to be as specific as possible, responses received like 'efiling is good' could not represent a critical incident for this research as it does not reveal anything regarding a service quality characteristic. Other times one aspect reported by a tax practitioner could relate to two different service characteristics and could then be split into more than one critical incident for purposes of analysis. The following is such an example as it relates to both the speed of the e-filing system as well as the preference of tax practitioners to have differentiated treatment with their own e-filing platform separate from the general public.

The efiling system is frustrating that it becomes slow and unusable during peak periods, we are practitioners who help make sure people are compliant, and basically ensure revenue collection. By using your system we are subjected to system lag due to SARS allowing the general population to use the system and it is beyond irritating. We should have separate servers etc. to prevent this. [12.3]

Hence, for the purposes of this research, critical incidents were defined as stand-alone positive and negative e-service quality statements about the services provided by SARS. Only critical incidents as defined were used in the data analysis. From the 811 responses, 1284 critical incidents related to the e-services of SARS were identified and analysed.

After the critical incidents were identified, the second step is to develop a classification scheme. 
Schneider and White (2004) is of the opinion that in developing the classification scheme existing models could serve as a framework or basis to be modified and changed to fit the needs of specific contexts. The E-S-Qual multi-item scale for assessing e-service quality as developed by Parasuraman et al. (2005) was used as the basis for the classification scheme. A sample of the responses (164 responses) were analysed by the researcher to refine and adjust the classification scheme. In applying the classification scheme to the bulk of the data, the classification scheme was amended in a constant process which resulted either in the expansion of the definitions of current categories or in the addition of new categories. The critical incident technique was thus used in this research to assist in the development of new e-service quality aspects and to confirm service quality aspects identified in the literature review.

The third and final step - the analysis of the critical incidents and their categorisation into the classification scheme - was performed by the researcher and seven research assistants. The research assistants had recently completed their Honours degrees that included a research project and a research methodology course and were thoroughly trained. They were required to read background information relating to service quality in general, the critical incidents technique, content analysis of data and information regarding tax processes and service channels. They were also required to classify a sample of responses. They were instructed to re-classify until they have reached an interjudge reliability with the researcher of $80 \%$.

Each critical incident was independently classified by at least three but mostly four different persons. A minimum of $80 \%$ of the critical incidents of each group were reviewed by the researcher with an interjudge reliability of at least $80 \%$ for all the groups. The interjudge reliability was calculated using the most common reliability index and that is interjudge agreement (the total number of agreements between researcher and assistant divided by the total number of coding decisions analysed by researcher) as advocated by Gremler (2004); Johnson and Gustafsson (2000) 
and Perreault and Leigh (1989). According to Johnson and Gustafsson (2000) and Perreault and Leigh (1989), an agreement index of $80 \%$ is a reasonable cut-off level to determine whether content analyses are reliable.

The theoretical framework derived from the content analysis was then compared with the six relevant service quality measuring instruments as identified in the literature review, namely: Barnes and Vidgen (2007), Connolly et al. (2010), Hu et al. (2009), Parasuraman et al. (2005), Papadomichelaki and Mentzas (2011) and Rotchanakitumnuai (2008). The result of this comparison is the proposal of a survey instrument to be used in the evaluation of the e-service quality of a revenue authority.

\section{Presenting the e-service quality framework}

Of the total number of critical incidents that related to the e-services, $90.81 \%$ related to e-filing (the electronic platform for submission of tax returns in South Africa) and 9.19\% related to the general website. As suggested by Christobal et al. (2007) the same measuring instrument can be used for both the general website and the e-filing website.

The number of positive responses $(59.97 \%)$ also exceeded the number of negative responses (40.03\%). The results for the e-services were the inverse of the findings in respect of the total responses, where approximately $60 \%$ of the critical incidents were negative and approximately $40 \%$ of the critical incidents were positive. The fact that the e-services received such a high percentage of positive responses may indicate that the minimum requirement expected by the responding tax practitioners with regard to the e-services rendered by SARS was exceeded.

Apart from classifying critical incidents as positive or negative, the content analysis of the critical incidence identified various service attributes. By using natural language argument, the service attributes identified were clustered into different e-service dimensions as identified in the 
Parasuraman et al. (2005) in their E-S-Qual measuring instrument. The following e-service dimensions were found to be relevant in building the 'lens of the tax practitioner', namely Fulfilment, Convenience, Efficiency, System availability, Reliability, Assurance, Empathy, Responsiveness, Security and Incentive. Also using natural language argument, the different service dimensions were classified into the different higher order e-service quality dimensions identified by Parasuraman et al. (2005). The following higher order dimensions - Normal operation dimension, the Assistance dimension and the Perceived value dimension - were relevant to this research.

The 'lens of the tax practitioner' encompasses the different service attributes, service dimensions and higher order service dimensions that are relevant in tax practitioners' evaluation of the e-service quality of a revenue agency (SARS). The proposed questions to be included in a survey instrument for the measurement of the 'lens of the tax practitioner' is presented next to each relevant service dimension (Table 1). 
Table 1:

NORMAL OPERATIONS SERVICE QUALITY DIMENSION

\begin{tabular}{|c|c|c|}
\hline $\begin{array}{c}\text { Service } \\
\text { dimension }\end{array}$ & Service attribute & Proposed questions for survey instrument \\
\hline Fulfilment & $\begin{array}{l}\text { - Scope of services offered } \\
\text { ○ Scope of services offered through e- } \\
\text { filing } \\
\circ \text { Completeness of the website } \\
\text { - Speed of service performance } \\
\text { ○ Turnaround time } \\
\circ \text { Timeliness of updates } \\
\text { - Accurate service delivery }\end{array}$ & $\begin{array}{l}\text { 1. E-filing provides for all required tax processes to be } \\
\text { performed electronically (Papadomichelaki \& } \\
\text { Mentzas, 2011). } \\
\text { 2. The website provides for all relevant information } \\
\text { (Barnes \& Vidgen, 2007; Papadomichelaki \& } \\
\text { Mentzas, 2011). } \\
\text { 3. E-filing enables me to file my tax return quickly } \\
\text { (Connolly et al., 2010; Hu et al., 2009; Parasuraman } \\
\text { et al., 2005). } \\
\text { 4. The turnaround time of everything submitted } \\
\text { through e-filing is prompt (Hu et al., 2009). } \\
\text { 5. E-filing provides its services at the times it promises } \\
\text { to do so (Hu et al., 2009). } \\
\text { 6. The website provides up-to-date data (Hu et al., } \\
\text { 2009; Papadomichelaki \& Mentzas, 2011). } \\
\text { 7. It is quick to download information or forms from } \\
\text { the website (Rotchanakitumnuai, 2008). } \\
\text { 8. Assessments received via e-filing are accurate (Hu } \\
\text { et al., 2009). }\end{array}$ \\
\hline Efficiency & $\begin{array}{l}\text { - Ease of use } \\
\text { - Organisation } \\
\text { - Speed of launching the site and pages } \\
\text { - Ease of finding information }\end{array}$ & $\begin{array}{l}\text { 9. I find e-filing easy to use (Barnes \& Vidgen, 2007; } \\
\text { Connolly et al., 2010; Hu et al., 2009; } \\
\text { Papadomichelaki \& Mentzas, 2011; Parasuraman et } \\
\text { al., 2005). } \\
\text { 10. The information on e-filing and the website is well } \\
\text { organized (Barnes \& Vidgen, 2007; Connolly et al., } \\
\text { 2010; Parasuraman et al., 2005; } \\
\text { Rotchanakitumnuai, 2008). } \\
\text { 11. E-filing launches and runs right away (Parasuraman } \\
\text { et al., 2005). } \\
\text { 12. E-filing and the website loads its pages fast } \\
\text { (Parasuraman et al., 2005). } \\
\text { 13. E-filing and the website enable me to get on to it } \\
\text { quickly (Parasuraman } \text { et al., 2005). } \\
\text { 14. E-filing and the website make it easy to find what I }\end{array}$ \\
\hline
\end{tabular}




\begin{tabular}{|c|c|c|}
\hline & & $\begin{array}{l}\text { need (Connolly et al., 2010; Parasuraman et } \\
\text { al., 2005). } \\
\text { 15. E-filing and the website make it easy to get } \\
\text { anywhere on the site (Parasuraman et al., 2005). }\end{array}$ \\
\hline $\begin{array}{l}\text { System } \\
\text { availability }\end{array}$ & $\begin{array}{l}\text { - Pre-testing } \\
\text { - Crash and freeze problems }\end{array}$ & $\begin{array}{l}\text { 16. All forms and services on e-filing have been pre- } \\
\text { tested and are correct (own question). } \\
\text { 17. E-filing is available and accessible whenever you } \\
\text { need it (Connolly et al., 2010; Parasuraman } \text { et al., } \\
\text { 2005; Rotchanakitumnuai, 2008). } \\
\text { 18. E-filing effectively supports high volume tax filing } \\
\text { transactions without system failure/breakdown } \\
\text { (Connolly et al., 2010; Papadomichelaki \& } \\
\text { Mentzas, 2011; Parasuraman et al., 2005). } \\
\text { 19. Pages on e-filing do not freeze after I enter or } \\
\text { submit information (Connolly et al., 2010; } \\
\text { Parasuraman } \text { et al., 2005). }\end{array}$ \\
\hline Security & 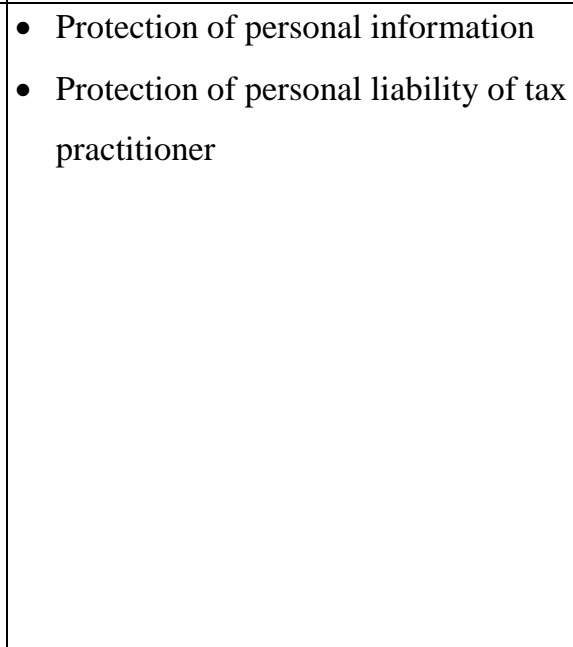 & $\begin{array}{l}\text { 20. E-filing does not share personal information with } \\
\text { other sites (Barnes \& Vidgen, 2007; Connolly et al., } \\
\text { 2010; Papadomichelaki \& Mentzas, 2011; } \\
\text { Rotchanakitumnuai, 2008). } \\
\text { 21. E-filing protects information about tax returns and } \\
\text { payments (Barnes \& Vidgen, 2007; Connolly et al., } \\
\text { 2010; Hu et al., 2009; Papadomichelaki \& Mentzas, } \\
\text { 2011). } \\
\text { 22. The tax practitioner is not responsible for the } \\
\text { correctness of the information submitted on behalf } \\
\text { of the taxpayer (own question.) }\end{array}$ \\
\hline
\end{tabular}

PERCEIVED VALUE DIMENSION

\begin{tabular}{|c|c|c|}
\hline $\begin{array}{c}\text { Service } \\
\text { dimension }\end{array}$ & Service attribute & Proposed questions for survey instrument \\
\hline Convenience & $\begin{array}{l}\text { - } \text { Time saving } \\
\text { - Electronic filing system } \\
\text { - Reduction of effort } \\
\text { - When I want it } \\
\text { - Cost saving } \\
\text { - Where I want it }\end{array}$ & $\begin{array}{l}\text { 23. It is convenient to use e-filing (Parasuraman et al., } \\
\text { 2005). }\end{array}$ \\
\hline Incentive & - Incentive & $\begin{array}{l}\text { 24. There is an incentive in using e-filing } \\
\text { (Papadomichelaki \& Mentzas, 2011). }\end{array}$ \\
\hline
\end{tabular}




\section{ASSISTANCE DIMENSION}

\begin{tabular}{|c|c|c|c|}
\hline Service dimension & Service attribute & & Proposed questions for survey instrument \\
\hline Reliability & - Accurate service delivery & & $\begin{array}{l}\text { Employees always assist in a way that my } \\
\text { problem with e-filing is solved (own question). }\end{array}$ \\
\hline Assurance & $\begin{array}{l}\text { - Knowledge and skills of } \\
\text { employees }\end{array}$ & 26. & $\begin{array}{l}\text { Employees have the knowledge to answer users' } \\
\text { questions (Rotchanakitumnuai, 2008). } \\
\text { Employees have the ability to convey trust and } \\
\text { confidence (Rotchanakitumnuai, 2008). }\end{array}$ \\
\hline Empathy & - Waiting time & 28. & $\begin{array}{l}\text { If I have a problem with e-filing I can very quickly } \\
\text { get hold of an employee to assist (own question). }\end{array}$ \\
\hline Responsiveness & $\begin{array}{l}\text { - Speed of performing the service } \\
\text { - Willingness of employees }\end{array}$ & $\begin{array}{l}30 . \\
31 .\end{array}$ & $\begin{array}{l}\text { Employees give prompt replies to users' inquiries } \\
\text { (Parasuraman et al., 2005; Rotchanakitumnuai, } \\
\text { 2008). } \\
\text { When e-filing promises to do something by a } \\
\text { certain time it does so (Hu et al., 2009). } \\
\text { Employees showed a sincere interest in solving } \\
\text { users' problems (Rotchanakitumnuai, 2008). }\end{array}$ \\
\hline
\end{tabular}

\section{Qualitative validation of the e-service quality framework as presented}

The E-S-Qual scale can be regarded as an e-service quality measuring instrument with a high degree of validity that is applicable globally in both the private and the public sectors. A comparison of the proposed e-service quality framework with the E-S-Qual scale may therefore contribute to the reliability of the e-service quality framework proposed in the present research.

Firstly, E-S-Qual is divided into four different higher order dimensions, namely Normal services, Recovery services, Perceived value and Loyalty intentions. In principle, both E-S-Qual and the framework proposed in the present research agree with regard to the definitions for three - Normal services, Recovery services and Perceived value - of the four E-S-Qual higher order dimensions. This supports the results of Boshoff (2007), who found that the E-S-Qual's four-dimensional configuration is not necessarily valid for all service settings. Parasuraman et al. (2005) indicated that all the items that were part of the Perceived value and Loyalty higher order dimensions could 
be deleted or modified for service settings without necessarily jeopardizing the integrity of the eservice quality scale. The Loyalty dimension as a whole was not found to be relevant to the present research. Three of the four items classified under the Perceived value dimension in E-S-Qual were also not found to be relevant to the present research.

In the Normal services higher order dimension, all the identified service dimensions (Efficiency, System availability, Fulfilment and Security) were relevant to the present research. Parasuraman et al. (2005) acknowledge that all phases of their research focused on websites that sold physical products (in contrast to pure service sites, such as those offering financial or information services). They suggest that their scale may not be fully applicable to service settings. However, they suggest that all items under the Efficiency, System availability and Security dimensions of E-S-Qual are germane to pure service sites as well. All the service attributes in the Efficiency, System availability and Security dimensions were as suggested found to be relevant to the e-service quality framework proposed in the present research.

The Recovery services higher order dimension in E-S-Qual is divided into three different service dimensions, namely the Responsiveness, Compensation and Contact. The Contact service dimension was not found to be relevant, although Parasuraman et al. (2005) suggested that it should be relevant to service settings. It is proposed that it may only be relevant in service settings when more than one service provider is available for a specific service. The Compensation service dimension in the E-S-Qual scale relates to compensation for the inconvenience of having to return damaged goods. SARS, firstly, only renders services, and, secondly, does not compensate tax practitioners (taxpayers) for incorrect service delivery. The Compensation service dimension was therefore also not found to be relevant to the present research.

Parasuraman et al. (2005) did not specify the items in the Fulfilment, Responsiveness and Compensation service dimensions that should be relevant. They only referred to the fact that they 
regard several items as applicable. As discussed above, the Compensation service dimension as a whole was not found to be relevant to the present research. Several of the service attributes in the Responsiveness (three out of five) and the Fulfilment service dimensions (three out of seven) were found to be relevant to the present research.

The e-service quality framework proposed in the present research also includes additional items that are not part of E-S-Qual. The original authors of SERVQUAL (Parasuraman et al. 1991) argue that the integrity of the SERVQUAL scale could be influenced when items are deleted from the scale. These authors did not express the same concern about the addition of items. The conclusions these authors made in relation to the SERVQUAL scale may also be relevant to the E-S-Qual scale. The addition of items should therefore not necessarily influence the integrity of the proposed framework.

The congruence between E-S-Qual and the proposed e-service quality framework should support the content validity of the proposed e-service quality framework.

\section{Conclusion}

Tax revenue forms the backbone of the South African economy. This underlines the need to enhance taxpayer compliance or reduce administrative costs in collecting taxes. The quality of the e-services provided by SARS is crucial, as e-service quality directly influences the burden of complying with tax obligations, and hence directly affects the tax compliance climate in a country.

The aim of this research was to develop an e-service quality framework that encapsulates the 'lens of the tax practitioner'. This research provides a basis for other researchers and may also stimulate the momentum of e-service quality research in the tax agency environment. Although the present research assists in the development of an e-service quality framework for SARS, the results provide only a theoretical framework and propose the measuring instrument to be used in evaluating the e- 
services of SARS. This measuring instrument should now be tested among a sample of tax practitioners. A reliable and concise measuring instrument is needed to enable SARS (or any independent third party) to conduct research into the quality of its e-services to tax practitioners. This would empower SARS to manage its e-service quality offerings to ensure increased tax compliance in South Africa.

\section{LIST OF REFERENCES}

Arkinci, S., Atilgan-Inan, E. \& Aksoy, S. (2010). Re-assessment of E-S-Qual and E-RecS-Qual in a pure service setting. Journal of Business Research, 63(3), March, 232-240.

Asubonteng, P. \& McClearly, K.J. (1996). SERVQUAL revisited: a critical review of service quality. Journal of Service Marketing, 10(6), 62-81.

Barnes, SQ. \& Virgin, RAT. (2002). An integrative approach to the assessment of e-commerce quality. Journal of Electronic Government Research, 3(3), 114-127.

Barnes, S. \& Virgin, R. (2007). Interactive e-government: Evaluating the web site of the UK Inland Revenue. Journal of Electronic Government Research, 3(1), 19-37.

Berry, L.L., Zeithaml, A. \& Parasuraman, A. (1985). Quality counts in services, too. Business Horizons, May/June, 44-52.

Berry, L.L., Seiders, K. \& Grewal, D. (2002). Understanding service convenience. Journal of Marketing, 66, 1-17.

Bitner, M.J. (1990). Evaluating service encounters: the effects of physical surroundings and employee responses. Journal of Marketing, 54, 69-82.

Boshoff, C. (2007). A psychometric assessment of E-S-Qual: a scale to measure e-service quality. Journal of Electronic Commerce Research, 8(1), 101-114. 
Childers, T.L., Carr, C.L., Peck, J. \& Carson, S. (2001). Hedonic and utilitarian motivations for online retail shopping behaviour. Journal of Retailing, 77, 511-535.

Collier, J.E. \& Bienstock, C.C. (2006). Measuring service quality in e-retailing. Journal of Service Research, 8(3), 260-275.

Connolly, R. \& Bannister, F. (2008). eTax Filing \& Service Quality: The case of the revenue online service. Proceedings of World Academy of Science, Engineering and Technology, 48 (April), 313-317.

Connolly, R., Bannister, F. \& Kearney, A. (2010). Government website service quality: a study of the Irish revenue online services. European Journal of Information Systems, 19, 649-667.

Cooper, D.R. \& Schindler, P.S. (2001). Business research methods. (7 ${ }^{\text {th }}$ ed.). New York: McGrawHill.

Cox, J. \& Dale, B.G. (2001). Service quality and e-commerce: an exploratory analysis. Managing Service Quality, 11, 2; ABI/INFORM Complete.

Cronin, J.J. \& Taylor, S.A. (1992). SERVPERF versus SERVQUAL: Reconciling performancebased and perceptions-minus-expectations measurement of service quality. Journal of Marketing, 58(1), 125-131.

Czepiel, J.A., Solomon, M.R., Surprenant, C. F. \& Gutman, E.G. (1985). Service encounters: an overview. In: Czepiel, J.A., Solomon, M.R., Surprenant, C. F. (Eds.), The service encounter: managing employee/customer interaction in service business (pp. 3-15). Lexington, MA: New York University Press.

Dabholkar, P.A., Shepherd, C.D. \& Thorpe I.T. (2000). A comprehensive framework for service quality: an investigation of critical conceptual and measurement issues through a longitudinal study. Journal of Retailing, 76(2), 139-173. 
Donnelly, M. \& Shiu, E. (1999). Assessing service quality and its link with value for money in a UK local authority's housing repair service using the SERVQUAL approach. Total Quality Management, 10(4/5), 598-506.

Feld, L.P. \& Frey, B.S. (2002), Trust breed trust: How taxpayers are treated. Economics of Governance, 3, 87-99.

Flanagan, J.C. (1954). The critical incident technique. Psychological Bulletin, 51(4), 1-33.

Gangl, K., Meuhlbacher, S., De Groot, M., Goslinga, S., Hofmann, E., Kogler, C., Antonides, G. \& Kirchler, E. (2013). “How can I help you?” Perceived service orientation of tax authorities and tax compliance. Paper presented at the International Shadow Economy Tax evasion and Governance Conference, July 25-28.

Garvin, D.A. (1984). What does "Product Quality" really mean? Sloan Management Review, 26(1), 25-40.

Gaster, L. \& Squires, A. (2003). Providing quality in the public sector: a practical approach to improving public services. Maidenhead, PA: Open University Press.

Gremler, D.D. (2004). The critical incident technique in service research. Journal of Service Research, 7(1), 65-89.

Grönroos, C. (1984). A service quality model and its marketing implications. European Journal of Marketing, 18(4), 36-44.

Grönroos, C. (1988). Service quality: the six criteria of good perceived service quality. Review of Business, 9(3), 10-13.

Hu, P.J., Brown, S.A., Thong, J. Y. L., Chan, F. K. Y. \& Tam, K.Y. (2009). Dimensions of service quality and continuance intentions of online services: The case of eTax. Journal of the American Society for Information Science and Technology, 60(2), 292-306. 
Johnson, M.D. \& Gustafsson, A. (2000). Improving customer satisfaction, loyalty and profit - An integrated measurement and management system. San Francisco: Jossey-Bass.

Kim, M., Kim, J. \& Lennon, S.J. (2006). Online service attributes available on apparel retail web sites: an E-S-QUAL approach. Managing Service Quality, 16(1), 51-77.

Klaus, P.G. (1985). Quality epiphenomenon: the conceptual understanding of quality in face-to-face service encounter. In: Czepiel, J.A., Solomon, M.R., Surprenant, C. F. (Eds.), The service encounter: managing employee/customer interaction in service business (pp. 17-33). Lexington, MA: New York University Press.

Ladhari, R. (2010). Developing e-service quality scales: A literature review, Journal of Retailing and Consumer Services. doi:10.1016/j.jretconser.2010.06.003, 1-14.

Lee, G.G. \& Lin, J.F. (2005). Customer perceptions of e-service quality in online shopping. International Journal of Retail \& Distribution Management, 33(22), 161-176.

Leedy, P.D., \& Ormrod, J.E. (2010). Practical research. $\left(9^{\text {th }}\right.$ ed.). New Jersey, Upper Saddle River: Pearson Education.

Li, Y.N., Tan, K.C. \& Xie, M. (2003). Measuring web-based service quality. Total Quality Management, 13(5), 685-700.

Loiacono, E.T., Watson, R.T. \& Goodhue, D.L. (2002). WEBQUAL: a measure of website quality. American Marketing Association, 432-437.

Marx, J.M.M. (2005). Customer service as an indication of service quality in South Africa. Unpublished MSc (Consumer Science) thesis, University of Pretoria, Pretoria.

Meckovec, R., Bubas, G. \& Vrcek, N. (2007). A method for improvement of objectivity of eservice quality evaluation. Journal of Information and Organizational Sciences, 31(2), 1527. 
Meuhlbacher, S. \& Kirchler, E. (2010). Tax Compliance by Trust and Power of Authorities. International Economic Journal, 24(4), 607-610. Available at: http://dx.doi.org/10.1080/10168737.2010.526005.

Murphy, K. (2004). The role of trust in nurturing compliance: A study of Accused Tax Avoiders. Law and Human Behaviour, 28(2). Available from http://0www.jstor.org.innpac.up.ac.za/stable/4141745.

Nomdoe, H. \& Pather, S. (2007). Providing a holistic perspective to evaluating e-service quality in web-based systems: a multi-stakeholder approach. ACM International Conference Proceeding Series, 226, 97-105.

Odekerken-Schröder, G., Van Birgelen, M., Lemmink, J., De Ruyter, K. \& Wetzels, M. (2000). Moments of sorrow and joy: An empirical assessment of the complementary value of critical incidents in understanding customer service evaluations. European Journal of Marketing, 34(1/2), 107-125.

Olivier, R.L. (1993). Cognitive, affective, and attribute bases of the satisfaction response. Journal of Consumer Research, 20, 418-430.

Papadomichelaki, X. \& Mentzas, G. (2011). e-GovQual: a multiple-item scale for assessing egovernment services quality. Government information Quarterly, 29, 98-109.

Parasuraman, A., Zeithaml, V.A. \& Berry, L.L. (1985). A conceptual model of service quality and its implications for future research. Journal of Marketing, 49, 41-50.

Parasuraman, A., Zeithaml, V.A. \& Berry, L.L. (1986). SERVQUAL: A multiple-item scale for measuring customer perceptions of service quality, Cambridge. MA: Cambridge Marketing Science Institute.

Parasuraman, A., Zeithaml, V.A. \& Berry, L.L. (1988). SERVQUAL: A multiple-item scale for measuring consumer perceptions of service quality. Journal of Retailing, 64(1), 12-40. 
Parasuraman, A., Berry, L.L. \& Zeithaml, V. (1991). Refinement and reassessment of the SERVQUAL scale. Journal of Retailing, 67(4), 420-451.

Parasuraman, A., Zeithaml, V.A. \& Malhotra, A. (2005). E-S-QUAL - a multiple-item scale for assessing e-service quality. Journal of Service Research, 7(3), 213-233.

Perreault, W.D. (Jr) \& Leigh, L.E. (1989). Reliability of nominal data based on qualitative judgements. Journal of Marketing Research, 26, May, 135-148.

Philip, G. \& Stewart, J. (1999). Assessment of the service quality of a cancer information service using a new P-C-P attributes model. Managing Service Quality, 9(3), 167-179.

Pinho, J., De Lurdis Martins, M. \& Macedo, I. (2011). The effect of online service quality factors on internet usage: the web delivery system of the taxation department. International Journal of Quality and Reliability Management, 28(7), 706-722.

Richard, M.D. \& Allaway, A.W. (1993). Service quality attributes and choice behaviour. The Journal of Service Marketing, 7(1), 59-68.

Robledo, M.A. (2001). Measuring and managing service quality: integrating customer expectation. Managing Service Quality, 1(1), 22-31.

Rotchanakitumnuai, S. (2008). Measuring e-government service value with the E-GOVSQUALRISK model. Business Process Management Journal, 14(5), 724-737.

Rust, R.T., Zahorik, A.J. \& Keiningham, T.L. (1995). Making service quality financially accountable. Journal of Marketing, 59(2), 58-71.

Santos, J. (2003). E-service quality: a model of virtual service quality dimensions. Managing Service Quality, 13(3), 233-246.

SARS Practitioners Unit. (2007). Filing Season 2007. PractitionerNews, 1(10). Available at: http://www.sarsefiling.co.za/Filing2007/Filing2007_TaxPrac_Issue1.html 
Schneider, B. \& White, S.S. (2004). Service quality: Research Perspectives. Thousand Oaks, CA: Sage.

Seth, N., Deshmukh, S.G. \& Vrat, P. (2005). Service quality models: a review. International Journal of Quality \& Reliability Management, 22(9), 913-949.

Sigala, M. (2009). E-service quality and Web 2.0: expanding quality models to include customer participation and inter-customer support. The Service Industries Journal, 29(10), 1341-1358.

Smith, A. (2003). The Wealth of Nations. New York: Bantam Dell.

Smulders, S., Stiglingh, M., Franzsen, R. \& Fletcher, L. (2012). Tax compliance costs for the small business sector in South Africa establishing a baseline. eJournal of Tax Research, 10(2), 182-304.

Snyckers, T. (2006). Practitioners: Current state assessment. Pretoria: SARS.

Spreng, R.A. \& Mackoy, R.D. (1996). An empirical examination of a model of perceived service quality and satisfaction. Journal of Retailing, 72(2), 201-214.

Szymanski, D.M. \& Hise, RAT. (2000). e-Satisfaction: An initial examination. Journal of Retailing, 76(3), 309-322.

Tan, K.C., Xie, M. \& Li, Y.N. (2003). A service quality framework for web-based information systems. The TQM Magazine, 15(3), 164-172.

United States Treasury. (2008). IRS oversight board: annual report to congress. http://www.treas.gov/irsob/reports/2008/2007_e-Filing_report.pdf (Accessed 13 July 2013)

Vos, C.A. (2003). Rethinking paradigms of service - service in a virtual environment. International Journal of Operations \& Production Management, 23(1), 88-104.

Wellman, C., Kruger, F. \& Mitchell, B. (2005). Research Methodology. (3 ${ }^{\text {rd }}$ ed). Cape Town: Oxford University Press. 
Wofinbarger, M., \& Gilly, M.C. (2003). eTailQ: dimensionalizing, measuring and predicting retail quality. Journal of Retailing, 79(3), 183-198.

Yang, A., Jun, M. \& Peterson, T. R. (2004). Measuring customer perceived online service quality. International Journal of Operations \& Production Management, 24(11), 1149-1174.

Yaya, L.H.P., Marimon, F. \& Fa, M.C. (2012). Assessing e-services quality: the current state of ES-QUAL. Total Quality management and business excellence, 23(12), 1363-1378.

Yoo, B. \& Donthu, N. (2001). Developing a scale to measure the perceived quality of an internet shopping site (SITEQUAL). Quarterly Journal of Electronic Commerce, 2(1), 31-47.

Zeithaml, V.A., Parasuraman, A. \& Malhotra A. (2002). Service quality delivery through web sites: a critical review of extant knowledge. Journal of the Academy of Marketing Science, 30(4), $362-375$.

Zhang, X. \& Prybutok,V.R. (2005). A consumer perspective of e-service quality. IEEE Transactions on Engineering Management, 52(4), 461-477.

Zhu, F.X., Wymer, W. (Jr) \& Chen, I. (2002). IT-based services and service quality in consumer banking. International Journal of Service Industry Management, 13(1), 69-90. 